\title{
Peranan Hiperventilasi terhadap Penurunan Tekanan Intrakranial dalam Kasus Bedah Saraf
}

\author{
M Sofyan Harahap, Irwan Wibowo \\ Departemen Anestesiologi \& Terapi Intensif Fakultas Kedokteran Universitas Diponegoro-RSUP Kariadi \\ Semarang
}

\begin{abstract}
Abstrak
Hiperventilasi telah ditemukan sebagai salah satu cara untuk menurunkan aliran darah otak (cerebral blood flow) (CBF) sejak tahun 1920-an. Pada saat itu telah dilaporkan bahwa penggunaan hiperventilasi dapat mengurangi peningkatan tekanan intrakranial (intracranial pressure/ICP) dengan vasokonstriksi serebral sehingga mampu menurunkan volume darah di daerah serebral. Secara teoritis, manfaat hiperventilasi mungkin lebih khusus diharapkan pada pasien di mana peningkatan ICP terjadi terutama karena peningkatan volume darah otak akibat mekanisme vasodilatasi. Efek vasokonstriksi tersebut akan menghilang setelah $\mathrm{pH}$ pada ruang perivaskular kembali normal setelah 24 jam. Yang menjadi perhatian utama dalam metode ini adalah tindakan tersebut mampu menginduksi terjadinya iskemia serebral baik secara regional maupun global. Risiko kerusakan iskemik tersebut bergantung pada sejauh mana dan seberapa lama otak mengalami aliran darah yang rendah. Masih terdapat data yang kontroversial antara yang mendukung ataupun menentang penggunaan terapi hiperventilasi, namun menurut penelitian yang telah dilakukan, tindakan ini mampu menurunkan ICP jika dilakukan dalam jangka pendek. Pemantauan multimodalitas terhadap pasien tetap diperlukan untuk memantau keberhasilan dalam tindakan ini.
\end{abstract}

Kata kunci: Hiperventilasi; tekanan intrakranial; bedah saraf

JNI 2020; 9 (1): 60-70

\section{Hyperventilation Management for Decrease Intracranial Pressure in Neurosurgery Cases}

\begin{abstract}
Hyperventilation has been found as a way to reduce cerebral blood flow (CBF) since 1920s. At that time it was reported that the use of hyperventilation can reduce the increase in intracranial pressure (ICP) by causing cerebral vasoconstriction and decreasing cerebral blood volume. Theoretically, the benefits of hyperventilation may be more specifically expected in patients which has increasing ICP because of an increasing in blood volume and vasodilation mechanism. The vasoconstriction effect disappears after the $\mathrm{pH}$ in the perivascular space returns to normal after 24 hours. The main concern in treating patients with increased ICP using hyperventilation is to induce cerebral ischemia both regionally and globally. As with a stroke, the risk of ischemic damage depends on the extent and how long the brain experiences low blood flow. Controversial data still exists between those that support or oppose the use of hyperventilation therapy, but if hypocapnia monitoring is done to control the increase in ICP in the short term, hyperventilation therapy remains beneficial. Multimodality monitoring is needed so that hyperventilation therapy can be used safely in certain patients who may need this therapy.
\end{abstract}

Key words: Hyperventilation; intracranial pressure; neurosurgery

JNI 2020; 9 (1): 60-70 


\section{Pendahuluan}

Peneliti mulai mempelajari bahwa hiperventilasi merupakan salah satu cara untuk menurunkan aliran darah otak (cerebral blood flow/CBF) pada tahun 1920-an. Salah satu deskripsi paling awal yang mempelajari perawatan ini terdokumentasi pada tahun 1959 dimana dilaporkan bahwa penggunaan hiperventilasi dapat mengurangi peningkatan tekanan intrakranial (intracranial pressure/ICP). Hiperventilasi menginduksi vasokonstriksi arteriol, yang kemudian akan menurunkan $\mathrm{CBF}$ dan akhirnya terjadi penurunan tekanan intrakranial (intracranial pressure/ICP). ${ }^{1}$ Seiring berjalannya waktu, tatalaksana terapi ini banyak digunakan untuk penanganan peningkatan ICP pada cedera otak sekunder (secondary traumatic brain injury/sTBI). . Pada pertengahan tahun 1990-an, di pusat-pusat bedah saraf yang berlokasi di Amerika Serikat dan Inggris, tingkat pemanfaatan hiperventilasi masing-masing adalah sebesar $83 \%$ dan $97 \%$. Analisis pusat data Eropa yang dirilis pada tahun 2008 menunjukkan bahwa penggunaan profilaksis hiperventilasi selama 24 jam pertama setelah cedera otak traumatik (traumatic brain injury/TBI) ini digunakan lebih dari setengah kasus cedera otak traumatik. ${ }^{1,2}$ Selama cedera otak traumatik berlangsung, hipertensi intrakranial dapat menjadi suatu kondisi yang dapat mengancam jiwa jika tidak dikelola secara cepat dan adekuat. Peneliti menggunakan terapi hiperventilasi untuk menurunkan peningkatan tekanan intrakranial dengan memanipulasi fungsi autoregulasi yang berhubungan dengan reaktivitas $\mathrm{CO}_{2}$.

Menginduksi hipokapnia melalui mekanisme hiperventilasi dengan cara menurunkan tekanan parsial arteri karbon dioksida $\left(\mathrm{PaCO}_{2}\right)$, yang kemudian menginduksi proses vasokonstriksi di dalam otak sehingga menghasilkan resistensi arteriol. Penyempitan pembuluh darah otak menurunkan aliran darah otak, yang kemudian mengurangi volume darah otak, dan pada akhirnya akan menurunkan ICP pasien. Efek dari terapi hiperventilasi bersifat sementara, akan tetapi, resiko yang menyertai tindakan ini baik dalam hal fisiologi otak dan perubahan sistemik harus dipertimbangkan dalam penggunaannya.
Perdebatan yang paling menonjol dalam penatalakanaan ini adalah kejadian iskemia otak dan hipoksia jaringan. Dalam hal ini pemantauan oksigenasi otak diperlukan untuk mengurangi bahaya yang dapat terjadi akibat terapi ini dikarenakan banyak bukti dari hasil penelitian yang menunjukkan bahwa terdapat potensial efek buruk yang berkaitan dengan hiperventilasi sehingga terapi ini harus dihentikan. Akan tetapi, hal ini tetap merupakan topik yang kontroversial diantarabanyakpeneliti.Ulasaniniakanmenyoroti berbagai isu seputar penggunaan hiperventilasi sebagai terapi yang dapat mengendalikan peningkatan ICP pasca trauma intracerebral hematoma $(\mathrm{ICH})$, termasuk indikasi untuk pengobatan, potensi risiko, manfaat, dan diskusi tentang teknik apa yang dapat dapat diterapkan untuk menghindari komplikasi yang merugikan. ${ }^{4}$

\section{Definisi Hiperventilasi}

Terdapat kontroversi pada terminologi, dimana hiperventilasi sebenarnya adalah hipokapnia. Sejak ditemukan bahwa penurunan nilai $\mathrm{PaCO}_{2}$ di bawah kadar normal $(40 \mathrm{mmHg})$ dapat meningkatkan ventilasi alveolar, hiperventilasi menjadi identik dengan kondisi hipokapnia. Dalam ulasan ini, kami akan menggunakan istilah hiperventilasi yang kurang tepat (tapi jauh lebih umum). Hiperventilasi dapat didefinisikan sebagai "induksi dan atau pemeliharaan level tekanan $\mathrm{CO}_{2}$ dalam darah arterial di bawah kisaran normal." Dalam hal ini, level normal $\mathrm{PaCO}_{2}$ harus dikoreksi untuk tekanan barometrik pada ketinggian yang berbeda. ${ }^{1,2}$

\section{Fisiologi dan Patofisiologi}

Hiperventilasi menyebabkan peningkatan ventilasi alveolar $(\mathrm{AV})$, volume udara per menit yang memasuki zona pernapasan (bronkiolus, alveoli, dll.) yang juga berguna untuk pertukaran gas. Karena sebagian dari volume itu tetap berada di area di mana gas tidak berdifusi ke dalam aliran darah, AV dapat ditentukan dengan persamaan berikut (rumus. 1). Produksi $\mathrm{CO}_{2}$ seluler pasien bergantung pada beberapa variabel, termasuk diet, olahraga, suhu, dan aktivitas hormon (tiroid). Produksi $\mathrm{CO}_{2}$ tetap 
relatif stabil dan konstan, kecuali selama keadaan hipermetabolik berat. Jika transpor $\mathrm{CO}_{2}$ dan curah jantung tetap tidak berubah, kadar $\mathrm{PaCO}_{2}$ akan ditentukan secara terbalik oleh laju eliminasi $\mathrm{CO}_{2}$ melalui $\mathrm{AV} .{ }^{6} \mathrm{CO}_{2}$ adalah gas yang larut dan dapat terdifusi, yang ditransfer ke dalam tubuh dalam tiga cara berbeda: $10-15 \%$ volume $\mathrm{CO}_{2}$ dilarutkan menurut $\mathrm{PaCO}_{2}$ (Hukum Henry); $20-30 \%$ volume tersebut terikat dengan protein plasma dan hemoglobin yang membentuk kompleks karbamin, dan 65-70\% kemudian dikonversi menjadi asam bikarbonat/karbonat dalam sel darah merah dan plasma. ${ }^{5,6}$ Reaksi kompleks dari ketiga mekanisme ini membantu menjaga keseimbangan antara ion bikarbonat $\left(\mathrm{HCO}_{3}-\right)$ )-dan hidrogen $\left(\mathrm{H}^{+}\right)$(Gambar 1). ${ }^{5}$ Nilai $\mathrm{PaCO}_{2}$ normal berfluktuasi antara 35 hingga $45 \mathrm{mmHg}(4,7-6 \mathrm{kPa})$ pada suhu tubuh normal dan berada di permukaan laut, dengan tekanan barometrik $760 \mathrm{mmHg}$. Jika suhu tubuh menurun, kelarutan $\mathrm{CO}_{2}$ dan $\mathrm{PaCO}_{2}$ meningkat, akibatnya, nilai $\mathrm{CO}_{2}$ dan $\mathrm{PaCO}_{2}$ $\mathrm{AV}=\mathrm{RR}($ respiratory rate $) \mathrm{x}[\mathrm{VT}$ (volume tidal)VDS (volume dead space)]. ${ }^{1}$

$\mathrm{PaCO}_{2}=\mathrm{CO}_{2}$ production $-\mathrm{CO}_{2}$ elimination ${ }^{1}$

akan menurun. $\mathrm{PaCO}_{2}$ berkurang sebesar $4,5 \%$ untuk setiap penurunan 10 Celcius. ${ }^{1-3}$ Ventilasi alveolar memiliki hubungan terbalik dengan kadar $\mathrm{CO}_{2}$ alveolar; ketika AV meningkat, kadar $\mathrm{CO}_{2}$ alveolar menurun. Namun, $\mathrm{CO}_{2}$ alveolar memiliki hubungan langsung dengan tekanan parsial $\mathrm{CO}_{2}$ arterial $\left(\mathrm{PaCO}_{2}\right)$, yang

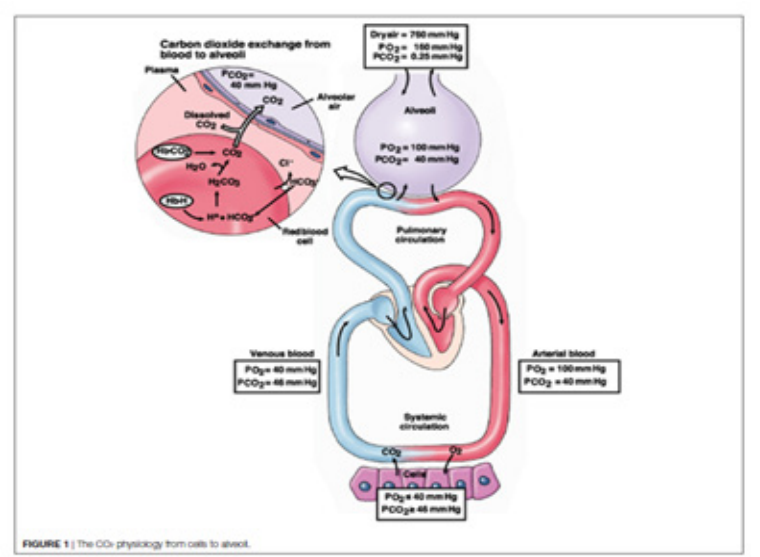

Gambar 1. Fisiologi $\mathrm{CO}_{2}$ dari Sel ke Alveoli. ${ }^{2}$ mencerminkan keseimbangan antara produksi dan eliminasi $\mathrm{CO}_{2} \cdot{ }^{2}$ Sistem saraf pusat memiliki porsi $2 \%$ dari berat badan (rata-rata berat otak sebesar 1.300 gr hingga 1.500 gr), dan sistem saraf pusat memiliki kebutuhan energi yang tinggi. Konsumsi oksigen otak adalah $3,5 \mathrm{~mL}$ per $100 \mathrm{~g} /$ menit, yang sesuai dengan $20 \%$ dari total konsumsi oksigen dalam tubuh. Dalam kondisi normal, CBF dipertahankan konstan dengan besar aliran dari 50 ke $60 \mathrm{~mL}$ per 100 $\mathrm{g} / \mathrm{menit}$, dimana $50 \mathrm{~mL}$ oksigen diambil setiap menitnya dari 700-800 $\mathrm{ml}$ darah (Tabel 1). ${ }^{2}$

Tingkat ekstraksi oksigen tinggi, dan rata-rata perbedaan $\mathrm{O}_{2}$ arteriovenousa untuk sistem saraf pusat adalah $6,3 \mathrm{~mL}$ per $100 \mathrm{~mL}$ darah. CBF tergantung pada tekanan diferensial antara arteri dan vena pada sirkulasi serebral, dan berbanding terbalik dengan resistensi pembuluh darah otak.Tekanan pada vena kapiler tidak dapat diukur, dan ICP, yang sangat dekat dengan tekanan vena, digunakan untuk memperkirakan tekanan perfusi otak/CPP. CPP dihitung sebagai perbedaan antara tekanan arteri rerata dan ICP. Nilai ICP normal pada orang dewasa adalah $<10 \mathrm{mmHg}$, dan ambang batas $20 \mathrm{mmHg}$ biasanya diterima untuk memulai pengobatan aktif. CPP sebesar $60 \mathrm{mmHg}$ umumnya diterima sebagai yang minimum nilai yang diperlukan sebagai nilai perfusi serebral yang adekuat. ${ }^{1,2}$ Dua konsep penting adalah doktrin Monro-Kellie dan kurva Volume-Tekanan.

Doktrin Monro-Kellie menyatakan bahwa volume total isi intrakranial (yaitu, jaringan otak, darah, dan cairan serebrospinal/CSF) tetap konstan

$$
\mathrm{V} \mathrm{C}=\mathrm{V} \text { otak }+\mathrm{V} \text { darah }+\mathrm{V} \mathrm{CSF}
$$

karena volume ini berada dalam kompartemen yang kaku (tengkorak), dengan rumus sebagai berikut:

Peningkatan volume salah satu komponen ini pada awalnya dapat dikompensasi dengan perpindahan bagian-bagian komponen lainnya. Vena serebral dapat dikompresi, menghasilkan penurunan volume darah otak, dan volume kompartemen CSF dapat menurun karena kombinasi peningkatan penyerapan dan perpindahan CSF 
Tabel 1. Nilai Normal dan Ambang Iskemia untuk Variabel Serebral Utama. ${ }^{2}$

\begin{tabular}{lll}
\hline \multicolumn{1}{c}{ Variabel } & \multicolumn{1}{c}{ Nilai normal } & \multicolumn{1}{c}{ Ambang batas untuk iskemik } \\
\hline Berat otak & $1.300-1.500$ & \\
$\mathrm{CBF}$ & $50-60 \mathrm{~mL} / 100 \mathrm{~g} / \mathrm{menit}$ & $<15 \mathrm{~mL} / 100 \mathrm{~g}$ \\
$\mathrm{OEF}$ & $30 \%$ & \\
$\mathrm{AVDO}_{2}$ & $6.3 \mathrm{~mL} \mathrm{O}_{2} / 100 \mathrm{~mL}$ darah & $>9 \mathrm{~mL} \mathrm{O}_{2} / 100 \mathrm{~mL}$ darah \\
$\mathrm{SjO}_{2}$ & $55-75$ & $<50$ \\
$\mathrm{PbrO}_{2}, \mathrm{~mm} \mathrm{Hg}$ & $<20$ & 15 \\
$\mathrm{ICP}, \mathrm{mm} \mathrm{Hg}$ & $\leq 10$ & \\
$\mathrm{CPP}, \mathrm{mm} \mathrm{Hg}$ & 60 & $<55-60$ \\
\multicolumn{2}{c}{$\mathrm{OEF}=$ oxygen extraction fraction } \\
\hline
\end{tabular}

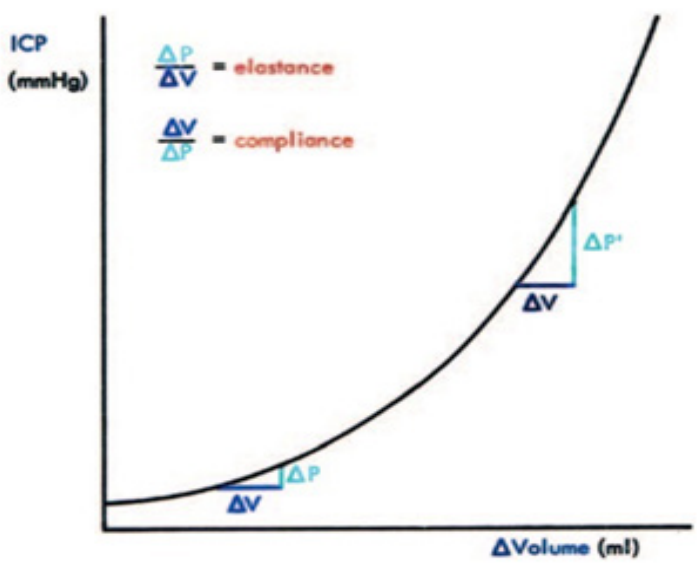

Gambar2. Kurvatekananvolume, menggambarkan peningkatan ICP secara eksponensial mengikuti peningkatan volume komponen intrakranial. ${ }^{1}$

menuju kompartemen tulang belakang. Ketika volume meningkat, mekanisme kompensasi habis, dan peningkatan volume secara lebih lanjut akan secara tajam meningkatkan nilai ICP, yang dijelaskan seperti dalam kurva tekanan volume yang digambarkan pada Gambar $2 .{ }^{1-4}$ Metabolisme otak yang tinggi dipadukan dengan tempat yang terbatas untuk tetap mempertahankan tingkat CBF dalam rentang normal. Dalam keadaan fisiologis, hal ini dilakukan melalui sejumlah mekanisme, yang secara umum disebut sebagai mekanisme autoregulasi. CBF meningkat dengan adanya mekanisme vasodilatasi dan menurun dengan penyempitan dari arteriolae otak, disebut cerebralresistance vessels.

Pembuluh darah ini merespon perubahan

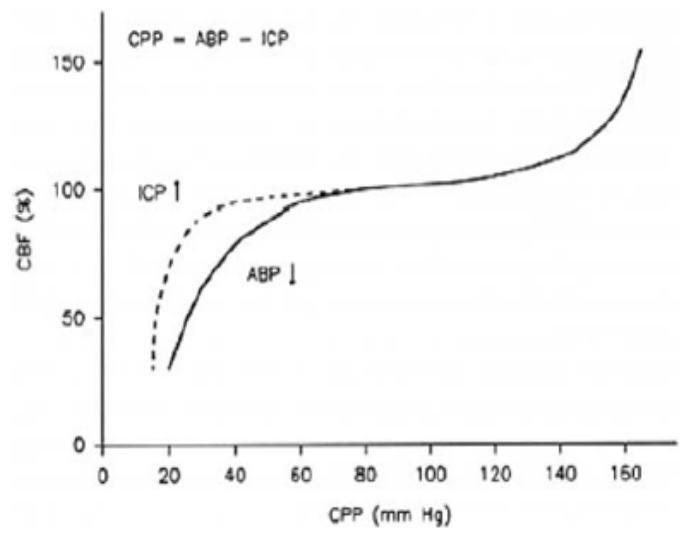

Gambar 3 . Kurva autoregulasi normal CBF vs CPP. CPP (cerebral perfusion pressure) dihitung sebagai tekanan arteri rerata (arterial BP [ABP]- ICP). Dengan meningkatnya ICP, CBF dipertahankan pada CPP yang lebih rendah dengan penurunan $\mathrm{ABP}$. $^{1}$

sistemik tekanan darah (tekanan autoregulasi), viskositas darah (autoregulasi viskositas), dan kebutuhan metabolik, untuk memenuhi nilai CBF yang berada di luar batas-batas yang tidak sesuai dan untuk memenuhi kebutuhan metabolisme. Autoregulasi tekanan ditunjukkan pada Gambar 2 dan $3 .{ }^{1-4}$

\section{Efek Sistemik Hiperventilasi}

Efek sistemik bersifat multifaktorial dan saling terkait, memengaruhi banyak area tubuh. Perbedaan substansial antara hiperventilasi aktif (ketika subyek secara sukarela meningkatkan ventilasi-nya) dan hiperventilasi pasif (dengan 
cara ventilasi buatan). Pada pasien dengan hiperventilasi aktif, aliran otonom sangat dipengaruhi, sedangkan pada yang hiperventilasi pasif efek $\mathrm{CO}_{2}$ dikombinasikan dengan interaksi kompleks antara ventilasi buatan dan hemodinamik. Selain itu, ketika hiperventilasi diterapkan untuk mengurangi ICP, biasanya kondisi ini Pentingnya efek sistemik hiperventilasi tidak diketahui. Selain itu, ketika hiperventilasi diterapkan untuk mengurangi ICP, biasanya kondisi ini dikombinasikan dengan berbagai intervensi, seperti penggunaan obat penenang, paralisis otot, dan peningkatan cairan yang masuk. ${ }^{8}$

\section{Efek Serebral pada Kondisi Hiperventilasi}

\section{Hiperventilasi dan ICP}

Hiperventilasi telah digunakan dalam mengelola cedera otak traumatik berat pada pasien yang berusia $>40$ tahun sejak Lundberg melaporkan penggunaan hiperventilasi dapat menurunkan peningkatan ICP pada tahun 1959.

HiperventilasimenguranginilaiICP, menyebabkan vasokonstriksi serebral dan menurunkan volume darah serebral. Fortune pada tahun 1995 menunjukkan bahwa penurunan arteri $\mathrm{PaCO}_{2}$ menjadi $26 \mathrm{mmHg}$ terjadi pada delapan individu sehat $(7,2 \%$ pasien $)$, dan volume darah serebral akan menurunkan CBF pada $30,7 \%$ pasien. Obrist pada tahun 1984 menunjukkan bahwa kondisi hiperventilasi akan menurunkan kadar ICP pada 15 dari 31 pasien dengan cedera otak traumatik berat, tetapi pada saat yang sama kadar ICP akan menurunkan CBF pada 29 dari 31 pasien.

Beberapa peneliti telah melaporkan hubungan antara $\mathrm{PaCO}_{2}$ dan ICP tidak bersifat linier, dan efek terbesar ditemukan pada pasien dengan nilai $\mathrm{PaCO}_{2}$ sebesar 30 hingga $50 \mathrm{mmHg}$. Dalam studi eksperimental pada rentang luas $\mathrm{PaCO}_{2}$, hubungan sigmoid antara ICP dan $\mathrm{PaCO}_{2}$ telah ditemukan. Dalam sebuah studi klinis pada 94 pasien dengan cedera kepala parah, telah ditemukan bahwa perubahan volume darah sebesar $0,5 \mathrm{~mL}$ diperlukan untuk menghasilkan perubahan ICP $1 \mathrm{mmHg}$. Konsisten dengan konsep kurva volume tekanan (Gambar 1), volume darah yang lebih rendah diperlukan untuk menghasilkan perubahan ICP yang signifikan pada pasien dengan penurunan kompliansi. Selanjutnya, efek ICP lebih besar ditemukan selama kondisi hiperkapnia daripada selama hipokapnia. Hasil serupa juga telah dilaporkan dengan menghitung rata-rata $( \pm \mathrm{SD})$ perubahan volume darah $0,72 \pm 0,42 \mathrm{~mL}$ untuk setiap milimeter perubahan merkuri dalam $\mathrm{PaCO}_{2}$. Yang mengejutkan, hanya sedikit penelitian yang membahas apakah efek menguntungkan ICP tetap terjadi selama mekanisme hiperventilasi yang berkepanjangan terjadi. Penelitian lain juga telah menekankan bahwa efek vasokonstriksi akan menghilang setelah $\mathrm{pH}$ pada ruang perivaskular kembali normal setelah 24 jam. Mereka dalam studi eksperimental lebih lanjut menunjukkan bahwa rebound vasodilatasi dapat terjadi bersamaan dengan risiko peningkatan ICP setelah mekanisme hiperventilasi terjadi. ${ }^{1}$

\section{Hiperventilasi dan $C B F$}

Perhatian utama dalam menerapi pasien dengan peningkatan ICP menggunakan mekanisme hiperventilasi adalah terapi ini berisiko menginduksi iskemia serebral, baik secara regional maupun global. Seperti pada stroke, risiko kerusakan iskemik bergantung pada sejauh mana dan lama otak mengalami aliran rendah (Gambar 4). ${ }^{1}$ Pada fase pasca-trauma awal, baik CBF global maupun regional menurun secara nyata, dan CBF yang rendah yang terjadi setelah cedera otak traumatik secara bermakna dikaitkan dengan kematian dini dan hasil yang lebih buruk. CBF dapat diukur, secara langsung atau tidak langsung, dengan sejumlah metode, namun tidak satupun yang dengan mudah tersedia di samping tempat tidur di lingkungan ICU. ${ }^{3}$ Pengukuran CBF dengan radioaktif $131 \mathrm{Xe}$, telah diperkenalkan untuk penggunaan klinis pada 1970 -an, namun teknik ini kemudian dilarang untuk digunakan secara klinis karena bahaya radiasinya. Setelah pengenalan pemindai $\mathrm{CT}$ multislice yang lebih cepat, pemindaian Xe-CT menjadi teknik standar untuk mengukur $\mathrm{CBF}$ dengan menggunakan Xe yang stabil dan non-radioaktif selama pemindaian CT otak. Xe yang terinhalasi, yang secara bebas terdifusi dari paru-paru ke pembuluh darah, dan dari pembuluh darah otak ke jaringan otak, dapat dideteksi di otak menggunakan pemeriksaan CT scan karena meningkatkan pelemahan sinar-x. ${ }^{3}$ 


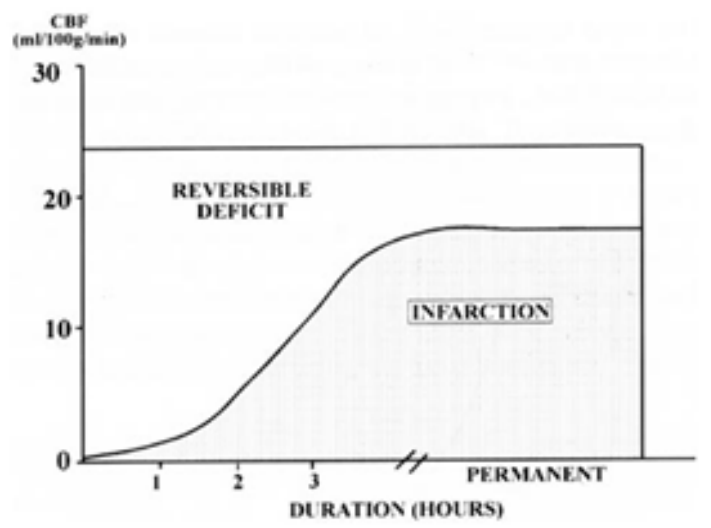

Gambar 4. Grafik yang menggambarkan hubungan antara penurunan $\mathrm{CBF}$, iskemia reversibel dan infark. $^{1}$

Pengukuran langsung CBF selanjutnya dapat dilakukan dengan pemindai Positron Emission Tomography (PET), yang menawarkan manfaat tambahan untuk menilai parameter metabolisme. Namun, pemindaian PET hanya tersedia di beberapa pusat penelitian; menyediakan, seperti juga kasus dalam pemindaian Xe-CT stabil, hanya informasi sesaat; dan melibatkan transportasi dari lingkungan ICU untuk periode waktu yang lebih lama. Pengukuran tidak langsung $\mathrm{CBF}$ dapat dilakukan dengan teknik ultrasonografi doppler $\mathrm{r}$ transkranial, yang memungkinkan pengukuran kecepatan aliran darah melalui arteri intrakranial basal. Kecepatan aliran darah, bagaimanapun, tidak secara langsung sesuai dengan $\mathrm{CBF}$, karena tidak ada informasi yang tersedia tentang diameter arteri serebral. ${ }^{11}$

Dengan menggunakan pemindaian Xe-CT untuk mengukur CBF regional ditemukan bahwa nilai CBF di bawah nilai ambang batas iskemik, yaitu sebesar $18 \mathrm{~mL}$ per 100 gram jaringan per menit pada $31 \%$ pasien dengan cedera otak traumatik. ${ }^{11}$ Dalam analisis retrospektif, pasien cedera otak traumatik dengan hematoma subdural, telah diamati bahwa nilai $\mathrm{CBF}$ terendah didapatkan dalam 24 jam pertama setelah cedera hematoma pada sisi yang sama. Studi dengan transcranial ultrasonography doppler juga telah menunjukkan bahwa keadaan kecepatan aliran rendah terjadi pada fase awal cedera, terjadi di $63 \%$ dari pasien. Karena nilai $\mathrm{CBF}$ rendah sering terjadi dalam
24 jam pertama setelah cedera otak traumatik, terdapat kekhawatiran khusus bahwa kondisi hiperventilasi akan meningkatkan risiko iskemia. Penelitian lain menggambarkan bahwa penurunan $40 \%$ nilai CBF selama 30 menit setelah penurunan $\mathrm{PaCO}_{2}$ sebesar 15 hingga $20 \mathrm{mmHg}$ terjadi pada sukarelawan sehat. Responnya hanya bersifat sementara dan setelah 4 jam CBF kembali menjadi $90 \%$ nilai dasar. Studi klinis pada pasien dengan cedera otak traumatik telah menunjukkan perubahan 3\% di CBF per milimeter perubahan merkuri di $\mathrm{PaCO}_{2}$, tapi yang respon lebih rendah pada pasien dengan tingkat $\mathrm{CBF}$ lebih rendah. Berbagai studi klinis telah mengkonfirmasi efek buruk hiperventilasi pada kadar CBF pada pasien dengan cedera otak traumatik. McLaughlin dan Marion pada tahun 1995 lanjut menunjukkan peningkatan vasoresponsivitas $\mathrm{CO}_{2}$ pada pasien dengan kontusio pada daerah penumbra, dan mereka berhipotesa bahwa kondisi hipersensitivitas ini dikombinasikan dengan hipoperfusi relatif dapat membuat lesi seperti ini rentan terhadap cedera iskemik sekunder, yang mungkin akan diperburuk oleh kondisi hiperventilasi. Penelitian yang dilakukan secara instan, menunjukkan bahwa hiperventilasi moderat tidak mengganggu metabolisme otak dan oksigen ekstraksi global pada pasien dengan TBI berat, meskipun penurunan yang jelas didapatkan pada CBF umum. Penelitian lain juga berpendapat bahwa penurunan nilai CBF akibat hiperventilasi dapat ditolerir apabila tidak didapatkan adanya perubahan parameter metabolik. ${ }^{12}$

\section{Hiperventilasi dan Oksigenasi Serebral}

Pemantauan oksigenasi serebral secara signifikan menunjukkan bahwa hiperventilasi secara signifikan berisiko menurunkan kadar CBF dan mungkin menginduksi atau memperburuk kondisi iskemia. Studi klinis telah berfokus pada oksimetri bulbus jugularis dan pemantauan tekanan oksigen jaringan otak $\left(\mathrm{PbrO}_{2}\right){ }^{3}$ Dalam oksimetri bulbus jugularis, $\mathrm{SjO}_{2}$ dipantau baik secara terus-menerus menggunakan teknik fiber optik kontinyu atau intermiten disertai dengan pengambilan sampel darah..$^{9}$ Oleh karena itu, teknik umum ini memberikan informasi mengenai ekstraksi oksigen dari drainase vena cerebral. Namun, kondisi ini tidak mencerminkan 
nilai hemisfer karena cross-flow mungkin terjadi, dengan satu vena jugularis mungkin lebih dominan. Umumnya pemeriksaan ini lebih disukai untuk mengukur/sampel dalam vena dominan. ${ }^{11}$

Dalam keadaan normal (misalnya, pada kondisi terjaga atau konsentrasi hemoglobin yang normal), nilai $\mathrm{SjO}_{2}$ berkisar antara 55 hingga $70 \%$. Nilai $\mathrm{SjO}_{2}$ di bawah $50 \%$ hingga $55 \%$ umumnya dianggap mewakili hipoperfusi serebral global dengan peningkatan ekstraksi oksigen otak. Informasi tambahan dapat diperoleh dengan menghitung $\mathrm{AVDO}_{2}$ atau menentukan fraksi ekstraksi oksigen. Beberapa penelitian menunjukkan bahwa hiperventilasi paksa, walaupun menormalkan ICP, dapat menyebabkan penurunan oksigenasi otak. Namun penelitian lain, telah menggambarkan bahwa nilai $\mathrm{SjO}_{2}>55 \%$ secara bersamaan dilakukan bersama dengan penurunan ICP. Dalam situasi eksperimental, ditemukan bahwa penurunan kandungan oksigen vena secara signifikan terjadi pada dua dari enam hewan yang mendapatkan terapi hiperventilasi, disertai dengan penurunan kadar fosfokreatin, dimana kondisi ini bersifat reversibel setelah pasien kembali mengalami normokapnia. Beberapa peneliti menyelidiki kondisi yang disebut flow-metabolism coupling dan menunjukkan bahwa pada sekitar $20 \%$ pasien dengan peningkatan aliran darah ICP melebihi kebutuhan metabolisme otak. Hiperventilasi dalam subkelompok ini dapat menurunkan nilai CBF dan memperbaiki ICP tanpa mereduksi oksigenasi serebral. ${ }^{9}$

Berbeda dengan pemantauan $\mathrm{SjO}_{2}$, pemantauan $\mathrm{PbrO}_{2}$ (partial pressure of brain tissue oxygen) adalah teknik regional. Sebagian besar penelitian tentang pemantauan $\mathrm{PbrO}_{2}$ juga telah menunjukkan efek negatif dari pemberian hiperventilasi oksigenasi otak. Pemantauan $\mathrm{PbrO}_{2}$ kontinyu mungkin terjadi ketika miniatur probe terbentuk, yang dapat dimasukkan ke dalam korteks serebral. Probe pertama adalah polarografi, sensor jenis Clark, di mana katoda dan anoda yang terkandung dalam membran bersifat permeabel terhadap oksigen. Ketika oksigen berdifusi dari jaringan ke probe, mekanisme ini akan menghasilkan arus listrik antara katoda dan anoda yang sebanding dengan tekanan oksigen. Selanjutnya, teknologi tambahan untuk pemantauan $\mathrm{PbrO}_{2}$ (yaitu, sistem kolorimetri) telah tersedia. Semua sistem menampilkan nilai numerik, mengekspresikan oksigen $10 \mathrm{mmHg}$. Nilai normal di otak berbagai spesies, termasuk manusia, adalah $>20 \mathrm{mmHg}$. Penurunan yang berkepanjangan dan mendalam harus bersifat independent dan menghasilkan hasil keluaran yang kurang baik dan menyebabkan kematian. ${ }^{9,10}$ Beberapa peneliti menunjukkan hubungan linear antara $\mathrm{PbrO}_{2}$ dan $\mathrm{CBF}$ dengan perubahan endtidal $\mathrm{CO}_{2}$ dan selanjutnya dikonfirmasi dengan hubungan antara $\mathrm{PbrO}_{2}$ dan end-tidal $\mathrm{CO}_{2}$ sebesar 20 hingga $60 \mathrm{mmHg}$. Berbagai penelitian eksperimental lainnya telah menunjukkan penurunan kadar $\mathrm{PbrO}_{2}$ akibat pemberian hiperventilasi. Dalam sebuah studi pada 16 babi, hasil penelitian menunjukkan bahwa penurunan kadar rata-rata $( \pm \mathrm{SD}) \mathrm{PbrO}_{2}$ sebesar $40 \%$, dari $36 \pm 11$ menjadi $20 \pm 9 \mathrm{mmHg}$ terjadi setelah hiperventilasi diberikan. Efek negatif hiperventilasi pada $\mathrm{PbrO}_{2}$ telah dikonfirmasi dalam banyak studi klinis. Dalam dua studi, bagaimanapun, efek deletorius $\mathrm{PbrO}_{2}$ tidak signifikan, dan beberapa studi bahkan telah melaporkan peningkatan $\mathrm{PbrO}_{2}$ dalam beberapa kasus. Hasil yang tampaknya bertentangan mungkin akan dijelaskan dengan adanya perbedaan patofisiologi antara pasien secara individual dan tampaknya akan mendukung optimalisasi pendekatan hiperventilasi, seperti yang dianjurkanseperti yg dianjurkan oleh beberapa peneliti. Pada pasien dengan peningkatan ICP yang terjadi akibat mekanisme vasodilatasi otak (hiperemia), hiperventilasi dapat mengembalikan aliran darah di daerah yang rusak. Hal ini juga ditunjukkan dengan adanya perbedaan respon $\mathrm{SjO}_{2}$ ketika dibandingkan dengan oksigenasi jaringan otak ketika $\mathrm{PbrO}_{2}$ kateter ditempatkan dekat dengan area lesi penumbra. ${ }^{1,2}$

\section{Hiperventilasi dan Manajemen}

Pasien dengan cedera otak traumatik derajat berat biasanya diintubasi dan mendapatkan ventilasi mekanis. Hipoksia, yang didefinisikan sebagai 
saturasi $\mathrm{O}_{2}<90 \%$, atau $\mathrm{PaO}_{2}<60 \mathrm{mmHg}$ harus dihindari. Hiperventilasi profilaksis dengan nilai $\mathrm{PaCO}_{2}<25 \mathrm{mmHg}$ tidak dianjurkan. Dalam 24 jam pertama setelah cedera otak traumatik berat terjadi, hiperventilasi harus dihindari, karena dapat secara lebih lanjut mengganggu perfusi otak yang sudah berkurang. Telah dilaporkan bahwa pada pasien dengan cedera otak traumatik, hiperventilasi meningkatkan volume jaringan yang sangat hipoperfusi di dalam otak yang mengalami trauma, meskipun terdapat perbaikan pada nilai CPP dan ICP. Penurunan perfusi otak regional ini dapat mewakili daerah-daerah jaringan otak yang berpotensi mengalami iskemik. Hiperventilasi yang berlebihan dan berkepanjangan menyebabkan vasokonstriksi serebral dan iskemia. Jadi, hiperventilasi direkomendasikan hanya sebagai tindakan sementara untuk mengurangi ICP yang meningkat. Hiperventilasi dengan periode yang singkat (15-30 menit), dengan kecepatan 20 napas per menit pada orang dewasa dan 25 napas per menit pada anak 10 atau $\mathrm{PaCO}_{2}$ sebesar 30$35 \mathrm{mmHg}$ dianjurkan untuk menerapi kerusakan neurologis akut yang terjadi akibat peningkatan $\mathrm{ICP}^{9}$.

Periode hiperventilasi yang lebih lama mungkin diperlukan untuk pasien dengan hipertensi intrakranial refrakter yang mendapatkan perawatan termasuk terapi sedatif, paralitik, drainase CSF, larutan salin hipertonik (HSS), dan diuretik osmotik. Namun, ketika hiperventilasi digunakan, pengukuran $\mathrm{SjvO}_{2}$ atau $\mathrm{PbrO}_{2}$ direkomendasikan untuk memantau oksigenasi serebral dan menghindari terjadinya iskemia serebral. Pengaturan ventilasi harus disesuaikan untuk mempertahankan nilai saturasi oksigen $\left(\mathrm{SpO}_{2}\right)>95 \%$ dan $/$ atau $\mathrm{PaO}_{2}>80 \mathrm{mmHg}$ dan untuk mencapai normoventilasi (eucapnia) dengan nilai $\mathrm{PaCO}_{2} 35$ hingga $40 \mathrm{mmHg}$. Beberapa peneliti melaporkan bahwa ventilasi dengan volume tidal yang tinggi merupakan prediktor independen dan berhubungan dengan cedera paru akut (ALI) pada pasien dengan cedera otak traumatik derajat berat. Oleh karena itu, ventilasi protektif dengan volume tidal yang rendah dan tekanan akhir ekspirasi positif sedang (PEEP) telah direkomendasikan untuk mencegah cedera paru terkait ventilator dan peningkatan ICP. ${ }^{9}$

\section{Hiperventilasi dan Hasil Klinis}

Meskipun penggunaan hiperventilasi dilakukan secara luas dalam terapi peningkatan ICP setelah cedera otak traumatik dan terdapat banyak bukti yang mengindikasikan bahwa hiperventilasi meningkatkan kadar CBF, oksigenasi, metabolisme, dan hanya satu uji prospektif klinis acak yang telah dilaporkan mempelajari hasil klinis dari pemberian hiperventilasi. Pada suatu penelitian membandingkan hasil keluaran pasien yang mendapatkan hiperventilasi dengan nilai $\mathrm{PaCO}_{2} 25 \mathrm{mmHg}$ selama 5 hari dengan pasien yang memiliki nilai $\mathrm{PaCO}_{2}$ sebesar $35 \mathrm{mmHg}$. Setelah 3 dan 6 bulan dari onset cedera, pasien dengan nilai motorik Glasgow Coma Scale 4 atau 5 memiliki hasil yang secara signifikan lebih baik ketika mereka tidak mendapatkan terapi hiperventilasi. Penelitian ini menjadi dasar untuk rekomendasi pada tingkat standar (bukti kelas I) dalam pedoman untuk manajemen cedera otak traumatik, menyatakan bahwa pada kondisi dimana peningkatan ICP tidak terjadi, terapi hiperventilasi yang memanjang $\left(\mathrm{PaCO}_{2}\right.$ $<25 \mathrm{mmHg}$ ) harus dihindari. Selain itu, pedoman tersebut menyatakan bahwa "penggunaan terapi hiperventilasi profilaksis $(\mathrm{PaCO} 2<35$ umum diberikan pada pasien dengan cedera otak traumatik, khususnya jika hiperventilasi perlu dilakukan. ${ }^{1,3,9}$

\section{Efek pada Sistem Organ}

Hipokapnia menurunkan perfusi pada sebagian besar sistem organ tubuh, termasuk jantung, hati, usus, otot rangka, dan kulit. Penurunan perfusi koroner akibat hipokapnia dapat meningkatkan risiko iskemia jantung pada pasien yang telah mengalami penyakit arteri koroner sebelumnya. Pada penelitian tahun 2017 ditemukan peningkatan ringan pada resistensi pembuluh darah sistemik dan penurunan ringan pada indeks jantung ketika hiperventilasi pasif ringan diberikan pada pasien dengan penyakit arteri koroner. Meskipun perubahan tekanan perfusi koroner dan aliran darah miokardium tersebut tidak bersifat signifikan, penurunan dalam $\mathrm{mm}$ $\mathrm{Hg}$ ) harus harus dihindari selama 24 jam pertama 
setelah cedera otak traumatik derajat berat karena dapat membahayakan perfusi otak selama CBF yang berkurang. Namun, pada kondisi elektif diakui bahwa terapi hiperventilasi mungkin perlu diberikan dalam periode yang singkat ketika kerusakan neurologis akut terjadi atau untuk periode yang lebih lama jika hipertensi intrakranial refrakter terhadap terapi lain. ${ }^{5}$

\section{Sintesis}

Penggunaan hiperventilasi dalam pengobatan pasien dengan cedera otak traumatik masih kontroversial. Hasil yang kontroversial telah telah digambarkan oleh berbagai editorial dan komentar literatur. Para pendukung hiperventilasi mengklaim bahwa teknik hiperventilasi efektif untuk menurunkan ICP dan bahwa, meskipun terapi ini juga dapat menurunkan $\mathrm{CBF}$, tidak ada bukti yang secara signifikan menyatakan bahwa teknik ini dapat menghasilkan gangguan metabolisme secara lebih lanjut, dan dari bukti-bukti ini mereka menyimpulkan bahwa risiko iskemia yang terjadi akibat pemberian hiperventilasi tidak terbukti. Kontroversi akan penggunaan teknik hiperventilasi menyatakan bahwa teknik ini menurunkan $\mathrm{CBF}$, oksigenasi otak, dan parameter neurokimia yang diperoleh dalam studi microdialysis. Selanjutnya, efek menguntungkan akan hasil keluaran klinis pasien juga telah ditekankan. ${ }^{11,12}$

Bagaimana kedua pandangan dan pendekatan yang berbeda tersebut dapat disatukan? Jawaban untuk pertanyaan ini menghasilkan diskusi umum tentang manajemen standar dan pendekatan yang lebih individual. Tidak jelas mengapa berbagai modalitas pengobatan harus bersifat eksklusif dan dapat mencakup semua area dalam manajemen trauma neurologis, bahkan pendukung teknik mekanisme hiperventilasi telah menekankan perlunya hiperventilasi yang optimal yang bertujuan memperbaiki ketidaksesuaian antara aliran dan metabolisme oksigen, dengan tujuan pemantauan multimodalitas termasuk pemantauan oksimetri jugular. ${ }^{12}$

Kelompok yang menentang pemberian hiperventilasi, menganjurkan terapi CPP, tetapi teknik ini juga memiliki kekuarangan karena memerlukan vasopressor dan menyebabkan kondisi hipervolemia, yang kemudian akan meningkatkan ICP, kelebihan cairan, dan meningkatkan risiko terjadinya ARDS. Kami menyampaikan bahwa kedua pendekatan mungkin menjadi tepat jika digunakan dalam kondisi yang tepat, sesuai dengan kondisi pasien secara individual. Resiko seperti yang dipaparkan dalam pedoman internasional pada hiperventilasi, menyatakan bahwa hiperventilasi berkepanjangan harus dihindari pada pasien cedera otak traumatik yang tidak mengalami peningkatan ICP. Sampai saat ini, tidak ada bukti dalam literatur yang secara jelas menunjukkan bahwa hiperventilasi yang diberikan pada pasien cedera otak traumatik dengan peningkatan ICP terkait dengan hasil yang lebih buruk, dan juga tidak ada bukti yang menunjukkan efek menguntungkan pada hasil pemberian terapi secara keseluruhan. Risiko sistemik akan tampak lebih besar, terutama pada pasien yang telah mengalami penyakit sebelumnya dan pada pasien dengan hipovolemia absolut atau relatif . Dalam hal ini, perlu dicatat bahwa hiperventilasi tidak disengaja sering terjadi pada kondisi pra-rumah sakit pada saat volume resusitasi optimal belum tercapai. ${ }^{12}$

Secara teoritis, manfaat hiperventilasi mungkin lebih khusus diharapkan pada pasien di mana peningkatan ICP terjadi terutama karena peningkatan volume darah otak akibat mekanisme vasodilatasi. Dalam praktik klinis, bagaimanapun, mungkin sangat sulit, jika bukan tidak mungkin, untuk membedakan antara kontribusi edema dan volume darah otak pada kondisi edema otak traumatis setelah cedera otak traumatik, tanpa fasilitas untuk pemindaian PET atau pencitraan difusi-tertimbang MRI. Dalam penelitian lain menunjukkan studi 31 pasien dengan cedera otak traumatik bahwa $2,94 \%$ edema otak terjadi karena adanya peningkatan volume darah otak rata-rata dibandingkan dengan rata-rata 9,1\% pasien yang benar-benar mengalami edema otak. Dalam kelompok pasien ini, volume darah otak meningkat hanya pada lima dari tujuh pasien. Namun, tidak disebutkan pada periode waktu mana studi ini dilakukan. ${ }^{12}$ 
Telah diperdebatkan bahwa risiko utama iskemia akibat hiperventilasi akan muncul dalam 24 jam pertama setelah cedera, karena periode ini merupakan periode di mana kadar menjadi CBF rendah. Kami berpikir bahwa pendapat yang diterima secara umum ini dapat ditentang. Jika memang fase akut tersebut ditandai dengan adanya kondisi penyempitan pembuluh darah, efek tambahan akibat mekanisme hiperventilasi dapat diharapkan menjadi rendah, dan hal ini telah terbukti dalam berbagai penelitian. Oleh karena itu, dapat disimpulkan secara tentatif bahwa terapi hiperventilasi mungkin lebih tepat dilakukan selama fase hiperemik relative, yaitu 2 hingga 3 hari setelah onset cedera otak traumatik. Namun demikian, risiko komplikasi iskemik tidak dapat dikesampingkan, dan pemantauan oksigenasi otak secara cermat diperlukan. ${ }^{12}$

Bukti saat ini akan mendukung durasi terapi hiperventilasi yang relatif singkat. Konsensus umum menyatakan bahwa teknik hiperventilasi tidak boleh diberikan pada pasien cedera otak traumatik dengan nilai $\mathrm{PaCO}_{2}$ kurang dari 30 mmHg. Pemantauan oksimetri jugularis dari ekstraksi oksigen otak dan pemantauan $\mathrm{PO}_{2}$ lokal pada jaringan otak dapat menghasilkan informasi tambahan pada area penumbra sekitar otak yang mengalami kontusio. Telah dilaporkan bahwa peningkatan vasoreaktivitas di zona penumbra di sekitar kontusio hingga hampir tiga kali normal dan menunjukkan kecenderungan hipersensitivitas area ini terhadap terapi hiperventilasi. Studi metabolik dengan MRI spektroskopi atau PET scan mungkin diperlukan sebelum kemungkinan efek lokal yang merugikan terjadi, sehingga semua efek merugikan dapat sepenuhnya dievaluasi. ${ }^{5}$

Ketika mempertimbangkan kedalaman terapi hiperventilasi yang tepat, dua kondisi tertentu harus diamati. Pertama, pada ketinggian yang lebih tinggi, kadar $\mathrm{PaCO}_{2}$ normal mungkin jauh di bawah kadar yang diterima secara umum yaitu 35 hingga $45 \mathrm{mmHg}$, yang ditentukan pada permukaan laut. Koreksi nilai $\mathrm{PaCO}_{2}$ harus dilakukan sesuai ketinggian permukaan laut. Kedua, pengaruh temperatur, terutama ketika terapi hipotermia harus dipertimbangkan. Di laboratorium, pengukuran gas darah umumnya dilakukan pada suhu $37^{\circ} \mathrm{C}$, dan hasilnya tidak dikoreksi sesuai dengan suhu inti tubuh. Validitas untuk melakukan koreksi suhu telah diperdebatkan. Penelitian yang telah dilakukan menunjukkan bahwa kondisi hipotermia dapat menyebabkan penurunan end-tidal $\mathrm{CO}_{2}$ dan $\mathrm{PaCO}_{2}$ karena adanya penurunan metabolisme sistemik dan otak. Pada kenyataannya, penulis tersebut berpendapat bahwa penurunan ICP beriringan dengan penurunan $\mathrm{PaCO}_{2} \cdot{ }^{5}$

\section{Simpulan}

Terdapat data-data yang kontroversial, yang mendukung ataupun menentang penggunaan terapi pilihan, baik data yang mendukung penggunaan terapi hiperventilasi berlebih, hingga data yang menghindari penggunaan hiperventilasi. Menurut pendapat kami apabila pemantauan hipokapnia dilakukan untuk mengontrol peningkatan ICP dalam jangka yang pendek, terapi hiperventilasi tetap bermanfaat. Pemantauan multimodalitas diperlukan agar terapi hiperventilasi dapat digunakan secara aman pada pasien tertentu yang mungkin memerlukan terapi ini.

\section{Daftar Pustaka}

1. Stocchetti N, Mass AIR, Chieregato A, Van der Plas AA. Hyperventilation in head injury. Chest Journal. 2005; 127:1812-27.

2. Godoy DA, Seif A, Garza D, LubilloMontenegro S, Murillo-Cabezas F. Hyperventilation therapy for control of posttraumatic intracranial hypertension. Front Neurol J. 2017; 8(250):1-13.

3. Brandi G, Stocchetti N, Pagnamenta A, Stretti F, Steiger P, Klinzing S. Cerebral metabolism is not affected by moderate hyperventilation in patients with traumatic brain injury. Biomedcentral J. 2019;23(45):1-7.

4. Carney N, Totten AM, O'Relly C, Ullman JS, Hawryluk G, Bell MJ, et al. Guidelines for the management of severe traumatic 
brain injury, Fourth Edition. Brain Trauma Foundation TBI Guidelines. 2016;4(8):1-10.

5. Guha A. Management of traumatic brain injury: some current evidence and application. Postgrad Med J. 2004;80: 650-53.

6. Marhong K, Fan E. Carbon dioxide in the critically ill: too much or too little of a good thing?. Respiratory Care J. 2014;59(10):1597-1605.

7. Dash HH, Chavali S. Management of traumatic brain injury patients. Korean Journal of Anesthesiology. 2018; February 71(1):12-21.

8. Dinnsmore J. Traumatic brain injury:an evidence-based review of management. Continuing Education in Anaesthesia, Critical Care and Pain J.2013;2: 1-7.

9. Haddad SH, Arabi YM. Critical care management of severe traumatic brain injury in adults. Scand $\mathrm{J}$ Trauma Resusc Emerg Med. 2012; 2(20): 1-15.

10. Henry M. Hiperventilation in severe traumatic brain injury. New York State Department of Health. 2003; SA:97-03.

11. Geeraets T, Vlly L, Abdennour L, Asehnoune K, Audibert G, Bouzat P, et al. Management of severe traumatic brain injury (first 24 hours). Anaesth Crit Care Pain Med. 2018; 37(2): 171-16.

12. Helmy A, Vizcaychipi M, Gupta K. Traumatic brain injury: intensive care management. $\mathrm{Br} \mathrm{J}$ Anaesth. 2007;99(1): 32-42.

13. Luo Y, Sun Y, Liu W, Liu T, Liu Z. The effect of permissive hypercapnia on cerebral oxygen metabolism and brain function in patients with craniocerebral trauma surgery. Biomed Research. 2017;28(15): 976-1683. 